\title{
RRAD Gene
}

National Cancer Institute

\section{Source}

National Cancer Institute. RRAD Gene. NCI Thesaurus. Code C18523.

This gene plays a role in signal transduction and is associated with diabetes mellitus. 